\title{
Teaching and Learning in the Summa theologiae of Gerard of Bologna (d. 1317)
}

Simon F. Nolan

ABSTRACT

Gerard of Bologna (d. 1317) was the first Carmelite master at the University of Paris in the Middle Ages. In Quaestio 6, article 1 of his incomplete Summa theologiae, Gerard discusses the issue of teaching and learning. During the course of his discussion he summarises his understanding of the process of cognition in human beings and he considers God, angels and human beings as teachers. Gerard insists on the necessity of the teacher-student relationship in the handing on of human knowledge.

\section{Introduction}

Gerard of Bologna (c. 1240/1250-1317) was the first master of the Carmelite order at the University of Paris in the Middle Ages. ${ }^{1}$ A student at Paris in the period associated with Henry of Ghent and Godfrey of Fontaines, he incepted as master there in 1295. In 1297 Gerard was elected Prior General of the Carmelites but continued to pursue his academic career while at the head of his order, combining both roles effectively until his death at Avignon in April 1317.

Gerard's authenticated works comprise one set of Quaestiones ordinariae (c.13051308), four sets of Quaestiones quodlibetales (c.1305-1308) and a Summa theologiae (c.13101317) which remained incomplete at the time of his death. ${ }^{2}$ In his works the Carmelite master reveals himself to be a frequent opponent of Thomas Aquinas. He is also an early critic of John Duns Scotus. ${ }^{3}$ Doctrinally Gerard is strongly influenced by Dominican authors such as James of Metz (fl. 1300) and Durand of Saint-Pourçain (c.1270-1334) and has strong affinities with Franciscan authors such as Peter John Olivi (c.1248-1298) and Walter Burley (c.1274-1344). Gerard is a frequent opponens of Hervaeus Natalis (1250/60-1323), Master General of the Dominican Order and strongest early defender of the teachings of Thomas Aquinas. ${ }^{4}$

\section{II}

\section{Summa, Quaestio 6, article 1}

Gerard's Summa, Quaestio 6 addresses the question of who, properly speaking, is the teacher of the science of theology. Article 1 addresses the specific question of whether

\footnotetext{
${ }^{1}$ For an account of the life and works of Gerard of Bologna see Bartomeu Xiberta, De scriptoribus scholasticis saeculi XIV ex ordine Carmelitarum (Louvain: 1931), pp. 74-110.

${ }^{2}$ For an excellent summary of the latest thinking concerning the dating of the works of Gerard of Bologna see Christopher Schabel, 'Carmelite Quodlibeta' in Christopher Schabel, ed., Theological Quodlibeta in the Middle Ages: The Fourteenth Century (Leiden: Brill, 2007), pp. 493-543.

${ }^{3}$ For a discussion of Gerard as an early critic of Scotus's philosophy of being see Stephen Brown, 'Gerard of Bologna's Quodlibet I, Quaestio 1: On the Analogy of Being' in Carmelus 31 (1984), pp. 143-170.

${ }^{4}$ See Xiberta, De scriptoribus, p. 91 for a discussion of the relationship between Gerard and Hervaeus. See also Schabel, 'Carmelite Quodlibeta', pp. 511-512.

${ }^{5}$ At his death in 1317 the Carmelite master had completed forty-four questions of his Summa. Quaestio 45 ends part of the way through article 5. For a general account of Gerard's Summa (together with an index quaestionum) see Bartomeu Xiberta 'De Summa theologiae Magistri Gerardi Bononiensis ex ordine Carmelitarum' in Analecta Ordinis Carmelitarum, 5 (1923), pp. 3-54. The edition of the text employed in this (C) - Simon F. Nolan, 'Teaching and Learning in the Summa theologiae of Gerard of Bologna (d. 1317)', in Maynooth Philosophical Papers, Issue 5 (2008), ed. by Simon Nolan (Maynooth: Department of Philosophy, National University of Ireland, Maynooth, 2009), pp. 35-41.
} 
God alone is such a teacher. The Carmelite master places his discussion firmly within the tradition of Augustine's De magistro opening with a quotation from that authoritative text. ${ }^{6}$ In general terms Gerard's discussion is clearly patterned on the Summa quaestionum ordinariarum of Henry of Ghent. ${ }^{7}$ After having considered a number of opinions Gerard begins his responsio noting that while to teach is in a way to cause knowledge in another not everything which causes knowledge is said to teach but only that which has knowledge 'in act' (actu). Dividing the article into sections, Gerard proposes a three-part discussion: 1) a general consideration of how knowledge is caused in the human soul; 2) how God, angels and human beings differ in the way they teach; 3) the teacher of the science of theology in particular. ${ }^{8}$

\section{III}

\section{The Process of Cognition in Human Beings}

Gerard begins his general discussion of how knowledge is caused in the soul of the individual by setting out his understanding of the process of cognition. The summary he provides here is immensely important since it is the only example we have in Gerard's surviving work of anything like a complete account of cognition; elsewhere he confines himself to specific issues. According to the Carmelite master the following are the 'elements' of human cognition: the possible intellect, the light of the agent intellect, the phantasms (or 'objects') and first principles. ${ }^{9}$ First principles, Gerard says, are like instruments of the intellect (quasi instrumenta intellectus) in acquiring knowledge. As a kind of afterthought Gerard acknowledges that, according to some (secundum quosdam), there are species in the intellect. We know that Gerard vehemently rejected any role for mediating species (sensible or intelligible) in the process of human cognition in his earlier Quodlibeta. ${ }^{10}$ There he always insisted on the phantasm and the agent intellect as being fit

article is taken from Paul de Vooght, Les sources de la doctrine chrétienne d'après les théologiens du XIV avec le texte integral des XII premières questions de la Summa inedited de Gérard de Bologne (†1317) (Versailles: 1954). Quaestio 6, article 1 is to be found on pp. 364-359. All references to the text of Gerard's Summa in this article note the Quaestio number, article number and page number in the de Vooght edition.

${ }^{6}$ Primo utrum solus deus sit doctor huius sciencie? Et videtur quod sic, quia Augustinus dicit in libro DE MAGISTRO: solus deus docet interius, qui cathedram babet intellectus. (Gerard, Summa, 6, 1: p. 364).

${ }^{7}$ See Henry of Ghent, Summa quaestionum ordinariarum (Paris: 1520), XI, 1, f. 76v, the title of which is identical to Gerard's Summa, Quaestio 6, article 1: utrum solus deus sit doctor huius scientiae.

${ }^{8}$ Respondeo dicendum quod quamquam docere est scienciam in alio causare, non tamen omne quod scienciam causat docere dicitur, sed ille tantum qui actu habet scienciam. Ideo, primo, aliqualiter uidendum in generali quomodo sciencia causatur in anima; secundo, ex hoc ostendetur quomodo differenter deus doceat, et creatura intellectualis uel racionalis. Tercio, descendetur ad doctorem huius sciencie in speciali. (Gerard, Summa, 6, 1; p. 364)

${ }^{9}$ Circa primum, sciendum quod ad scienciam acquirendam requiruntur ista, scilicet intellectus possibilis, lumen intellectus agentis, fantasmata siue obiecta et prima principia, que sunt quasi instrumenta intellectus in acquisicione sciencie et, secundum quosdam, species existentes in intellectu sunt. (Gerardus, Summa, 6, 1; pp. 364-365)

${ }^{10}$ For a long time commentators have considered the denial of the role of the species intelligibilis to be a defining characteristic of the cognitional theory of Gerard of Bologna. It was what most incurred the disapproval of Gerard's main academic opponent during his lifetime, the Dominican Hervaeus Natalis. The Franciscan Peter Auriol (c. 1280-1322) was an early critic of the Carmelite master's noetic on this point, arguing for mediating species in the process of cognition. For an account of Peter Auriol on the species doctrine see Leen Spruit, Species Intelligibilis: From Perception to Knowledge, I (Leiden: 1994), pp. 286-290. Later on, in 1880, Gerard won the approbation of French historian and publicist, Barthélemy Hauréau, precisely for the daring way in which he states his position. Hauréau comments: 'Félicitons Gérard de Bologne d'une telle initiative. Elle lui fait beaucoup d'honneur.' Barthélemy Hauréau, Histoire de la philosophie scolastique, II, 2 (Paris: 1880) p. 272. More recently Katherine Tachau sees Gerard as a pioneering figure who, with his elimination of the species, anticipates some of the tendencies that were to become important in later medieval thought: 'Gerard's position is historically interesting not least as the step for which among 
for purpose, without the aid of intermediate species. Here, in his Summa, Gerard is perhaps sounding a conciliatory note, acknowledging the opinion of others, without committing himself to the species doctrine.

Having set out the 'elements' Gerard proceeds to explain the dynamics of human knowing. How is human knowledge in general caused? ${ }^{11}$ Pride of place is accorded by Gerard to first principles. Once the possible intellect has knowledge of first principles it proceeds by means of this knowledge inwardly and moved by the light of the agent intellect and by the phantasm, it proceeds to know in an actual way what was already contained virtually (virtute) in the first principles. Gerard is at pains to insist that these first principles are known in a certain sense innately (innata non acquista), that they are known immediately, non-discursively and without the need for investigation (statim sine decursu et investigacione). Gerard informs the reader that he intends addressing the issue of first principles later in his Summa. Unfortunately this plan remains unrealised in the sections he managed to complete.

Moving on to address the question of how God and rational creatures differ in the way they teach, Gerard considers for a moment the possibility of teaching oneself. The Carmelite master recognises someone may acquire knowledge by means of their own inventiveness and application but, strictly speaking, such a person cannot be said to teach himself or herself. ${ }^{12}$ Such a person does not have actual but only virtual knowledge before them, such knowledge as is contained in first principles and in the light of the agent intellect. However, such a person could never be said to have been taught in such a situation. One who teaches, Gerard insists, is one who has actual knowledge or knowledge 'in act' (actu). Here, the Carmelite master cites Aristotle. At the beginning of the Metaphysics Aristotle claims a sign or mark of those who actively know is that they can teach. For Aristotle (and Gerard who follows him) there is, therefore, an intimate connection between knowledge and the ability to teach. The latter gives witness to the former. ${ }^{13}$ Gerard continues by noting that God, angels and human beings all have knowledge in act. Accordingly, each of them, in different ways, is able to teach those human beings who do not yet know.

\section{IV}

\section{Teachers: Divine, Angelic and Human}

Gerard considers divine, angelic and human teaching in turn. God teaches per se and interiorly (interius). ${ }^{14}$ God, therefore, is the total cause (tota causa) even of the possible

succeeding scholastics Ockham would receive almost exclusive credit'. Katherine Tachau, Vision and Certitude in the Age of Ockham: Optics, Epistemology and the Foundations of Semantics, 1250-1345 (Leiden: E. J. Brill, 1988) pp. 99-100.

${ }^{11}$ Causatur autem ex hiis sciencia in generali loquendo in hunc modum. Nam intellectus possibilis, habita noticia primorum principiorum que statim sine decursu et inuestigacione habetur, propter quod dicitur innata non acquisita, ut infra patebit, cum de habitibus intellectus agetur, procedit, mediante illa noticia, ad intus, lumine intellectus agentis et motus a phantasmatibus, raciocinando et discurrendo ad noticiam posteriorem que continetur uirtute in noticia primorum principiorum. Et sic acquiritur sciencia, ex notis ad ignota procedens, ut in sequentibus clarius exponetur, et hoc est primum. (Gerard, Summa, 6, 1; p. 365)

${ }^{12}$ Circa secundum, sciendum quod, quia ille qui acquirit scienciam per seipsum, uia inuencionis, non prehabet scienciam actu sed uirtute tantum, contentam scilicet in principiis primis et in lumine intellectus agentis, non dicitur docere seipsum, quia, ut supra dicebatur, ille docere dicitur qui scienciam habet actu. Vnde dicit Philosophus, primo METAPHYSICE, quod signum scientis est posse docere. Scienciam autem actu habet deus, angelus et homo. Et ideo quilibet istorum potest docere hominem ignorantem, diuersimode tamen. (Gerard, Summa, 6, 1; p. 365)

13 Aristotle, Metaphysica 981 b5.

${ }^{14} \mathrm{Nam}$ deus docet per se et interius. Ipse enim tota causa est intellectus possibilis et luminis naturalis agentis, supposito quod hoc sit aliquid anime, ut communiter dicitur. Quod pro tanto dico quode quidam posuerunt intellectum agentem esse deum, et tunc deus non esset causa eius, quia non est causa sui ipsius. Ipse eciam est principalis causa fantasmatum et specierum intelligibilium, si alique tales sint, et noticie 
intellect and of the natural light of the agent intellect in the human being. Gerard recognises that some hold the different opinion that the agent intellect is God himself and not, therefore, the cause of the agent intellect. God is also the principal causes of the phantasms and also of intelligible species. Once again, however, the Carmelite master distances himself from the species doctrine with the qualifying remark 'if there are such' (si alique tales $\sin t)$. God is also the principal cause of knowledge of first principles and of all deduction which follows.

Turning briefly to the issue of angelic cognition, Gerard recognises that angels teach human beings interiorly in a certain way (quodammado). ${ }^{15}$ One can use metaphors of light in this connection. As the human being moves towards knowledge, he or she may be said to move towards illumination but, the Carmelite master insists, only God illumines the human intellect (or is, at least, the cause of the natural light of the agent intellect); angels do not illumine the human intellect even as they bring human beings to know. Angelic teaching of humanity is effective 'by approximation' (per approximacionem), says Gerard. Once again Gerard tantalisingly declares his intention to provide a lengthy discussion of angelology, an intention sadly never realised.

\section{V}

\section{The Relationship between Teacher and Student}

Gerard now turns to human teaching and offers his own philosophy of human education. ${ }^{16}$ In contrast to God, the human being teaches exteriorly (exterius) by means of the spoken or written word, introducing new and unfamiliar ideas other than first principles, giving illustrative examples and leading the student 'by the hand' (manu) to new understanding. Such teaching does not proceed interiorly. The teacher engages the student from the outside, seeking to impart knowledge. Gerard seeks to give weight to his assertions with several quotations from Augustine, insisting that Augustine was well aware that his assertion that God is the principal teacher and that only God teaches interiorly in no way precludes the possibility of the human being teaching exteriorly.

At this point in his discussion Gerard signals a controversy among scholars (inter doctores). ${ }^{17}$ Scholars agree that human beings do not teach interiorly. Only God so teaches. However, scholarly opinion divides concerning the issue of whether the human being teaches per se or not. Gerard notes the opinion of some (aliqui) who insist that the human being teaches per se and that, therefore, the teacher is the cause of knowledge in the student per se and not merely accidentally (per accidens). Gerard summarises some of the proofs from Aristotle advanced by proponents of this view.

primorum principiorum et tocius deduccionis que sit ad scienciam acquirendam et ipsius sciencie iam adepte. Ideoque per se principaliter et interius docere dicitur, quod sibi soli conuenit. (Gerard, Summa, 6, 1; p. 365)

15 Angelus autem docet, ut quidam dicunt, quodammodo interius, attingendo ad lumen, non quidem sicut deus, quia deus lumen infundit ipsum creando, angelus autem non infundit lumen intellectus humani, sed confortat per approximacionem, sicut carbo ignitus confortatur ex apposicione alterius carbonis, uel alio modo consimili. De quo non plus ad presens, quia de hoc habet tractari, cum agetur de angelis. (Gerard, Summa, 6, 1; p. 365)

\footnotetext{
${ }^{16}$ Homo autem docet exterius uerbo uel scripto, per signa proponendo discipulo alicas proposiciones minus communes, subordinatas primis concepcionibus iam precognitis, quas ex prehabitis concipere potest, uel proponendo alica exempla sensibilia uel alica similia uel communia, ex quibus intellectus addiscentis manu ducitur ad scienciam capessendam. Nullo modo autem docet interius, quia ad principia interiora per que acquiritur sciencia, nullo modo attingit. Et quia sic docet exterius non interius, ideo inuenitur dictum a sanctis quod solus deus docet. (Gerard, Summa, 6, 1; p. 366)

${ }^{17}$ Sed utrum homo per se doceat, uidetur esse controuersia inter doctores. Nam aliqui dicunt quod homo per se docet, ita quod per se non per accidens est causa sciencie in discipulo. (Gerard, Summa, 6, 1; p. 366)
} 
A second group of scholars identified by Gerard adopt a complex position. Opposing the first group they insist that the human being does not teach per se. However, they also believe that it is not enough to counter the first opinion by stating simply that the human being teaches accidentally (per accidens). ${ }^{18}$ Proponents of this second view insist that the human being teaches 'accidentally per accidens' (accidentaliter per accidens). Furthermore, they insist that the human teacher teaches his or her students neither by placing objects before their intellective powers, nor by causing interior concepts (conceptus interiores) within them, but by means of 'verbal signs' (signa verborum). Such 'signs' neither cause the student to see the truth per se nor do they lead to the formation of concepts in the mind of those on the receiving end of a master's teaching.

Gerard recognises that this second opinion is rather obscure (hoc est aliqualiter obscurum) and that the accidentaliter per accidens formulation is difficult to grasp. ${ }^{19}$ By way of clarification the Carmelite master repeats for the benefit of the reader an example given by proponents of this second opinion. One human being can point out a star to another with his or her finger. Putting this another way, one makes the other see the star accidentally (per accidens). The star causes the vision in the one seeing it per se. The one who points with his or her finger to the star does not per se make the other see but brings about the conditions under which the star may be seen; he or she brings it about (per accidens) that the other may see the star. Again, the per se seeing of the star is caused by the star. For their part, according to proponents of the second opinion, verbal signs neither cause knowledge per se nor are they the per se cause of interior concepts which cause knowledge. They are mere accidental causes. And they are in a sense doubly accidental because they do not signify things naturally (naturaliter) but by setting things in place (per institucionem) for the student to form concepts in their minds. In this sense verbal signs, by means of which human beings teach, cause accidentally per accidens. Proponents of this second opinion are (as Gerard reminds us) fond of quoting Aristotle's Sense and Sensibilia which declares that hearing is the faculty that contributes most to growth in intelligence. ${ }^{20}$ Words cause instruction because they are audible but they do so accidentally since every word is a sign or symbol. Claiming to follow Aristotle, proponents of the second opinion insist, therefore, that verbal signs are key to teaching and learning. They cannot cause knowledge in the student per se since they are merely indicative. In this sense they cause accidentally. But verbal signs are also accidental as signs or symbols. The Carmelite master has done his best to give justice to an academic position he will now proceed to reject. $^{21}$

\footnotetext{
${ }_{18}$ Aliis autem uidetur quod homo doctor non solum sit causa per se sciencie discipuli, sed nec per accidens tantum, immo accidentaliter causa per accidens. (Gerard, Summa, 6, 1; p. 367)

${ }^{19}$ Et quia hoc est aliqualiter obscurum, ponunt isti exemplum tale. Aliquis digito ostendit alicui astrum in celo. Iste facit istum uidere astrum per accidens, quia nichil imprimit uisui, sed astrum facit per se quod iste uideat ipsum, quia imprimit ei uisionem sui. Licet autem ille qui digito ostendit astrum alteri non faciat illum per se uidere, per se tamen ducit oculum ad rectam posicionemc sub qua astrum uidetur; ideo facit astrum ab illo uideri per accidens. Sed signa uerborum nec per se causant scienciam, nec per se faciunt ad ordinacionem conceptuum interiorum qui per se sunt causa sciencie, sed solum per accidens, in quantum sermo est signatiuus rerum, non naturaliter, sed per institucionem, de quibus rebus formantur conceptus, et sic sunt causa doctrine accidentaliter per accidens. Et ideo dicit Philosophus, in libro DE SENSU ET SENSATO quod auditus, secundum accidens, ad scienciam plurimam confert partem. Sermo enim audibilis existens causa est discipline, non secundum se sed secundum accidens. Ex nominibus enim constat. Nominum uero unumquodque symbolum est. (Gerard, Summa, 6, 1; p. 367-368)

${ }^{20}$ Aristotle, De sensu et sensibili 437a10-15.

${ }^{21}$ Commenting on this passage from Gerard, de Vooght has the following to say: 'Gérard de Bologne hésite à longeur de colonnes entre per se et accidentaliter per accidens. La question est oiseuse. On le qulifiera comme on voudra - plutôt per se - , de toutes façons l'enseignement d'un maitre est nécessaire. Sans un maître on ne sort pas du labyrinthe'. Paul de Vooght, Les sources, p. 44.
} 
Gerard proceeds to declare his preference of the first opinion: that the human being teaches exteriorly per se. ${ }^{22}$ Yet again the Carmelite master proposes to return to the topic later in his Summa when he hopes to address the issue of how a human being is taught by another human being. For the moment he offers a succinct 'determination' of his own, revealing himself to be a skilful philosopher. While Gerard agrees that the human being teaches another human being per se, he readily recognises that this does not mean that the teacher causes knowledge in the mind of the student immediately and directly (immediate et directe). The Carmelite master insists that knowledge is not a mere quality such as coldness or hotness. A teacher orientates (per direccionem) a student by means of sensible signs, putting order on concepts from which knowledge may be acquired. Gerard is convinced that if the teacher were the mere accidental cause which accidentally caused knowledge in the student, then there would be no particular relationship (relacio vel babitudo) between teacher and student. ${ }^{23}$ Without the relationship between master and disciple (or teacher and student) there can be no bridging of the supposed gap between words and concepts, between the names standing for the concepts of human knowing and those concepts themselves. Returning to the second opinion Gerard states his firm conviction that Aristotle himself never intended to speak of the causality of rational discourse (sermo) as causing accidentaliter per accidens; such, according to the Carmelite master, is neither Aristotle's phraseology nor his intention. ${ }^{24}$ Furthermore, Gerard asserts, Aristotle considers such words as used by a teacher to instruct his or her student as more than mere audible sounds. A word so employed is something audible but it is more than that: it is a name with meaning (nomen significatiuum) and is a per se cause of knowing.

In the final part of Quaestio 6 Gerard considers those theological truths which cannot be known without the infusion of supernatural light into the human mind. In this area God may be said to be the only teacher. ${ }^{25}$

\footnotetext{
${ }^{22}$ Que autem istarum opinionum sit uerior, habet enucleatius infra uideri, ubi tractabitur qualiter homo ab homine doceri possit. Sed ad presens potest breuiter dici quod prima opinio uerior est, non tamen sic intelligendo quod doctor per suam scienciam immediate et directe causaret scienciam in mentem discipuli, quia nec mentem eius attingit, nec sciencia est qualitas actiua sicut caliditas uel frigiditas, sed per direccionem, mediantibus signis sensibilibus, ordinando conceptus ex quibus acquiritur sciencia. (Gerard, Summa, 6, 1; p. 368)

${ }^{23} \mathrm{Si}$ enim doctor accidentaliter per accidens esset causa sciencie in discipulo, tunc nulla specialis relacio uel habitudo esset inter discipulum et doctorem, quia omnis homo, immo forte quelibet res posset sic esse causa sciencie. Quilibet enim homo et quelibet res posset dare occasionem alicam alicui quod ad scienciam pertingeret, quod est esse causam accidentaliter per accidens. Et tunc eciam inter nomina significatiua conceptuum sciencialium et ipsos conceptus non esset alica determinata habitudo, nec alica sciencia de hiis tractans, quia nec habitudo determinata nec sciencia est de his que se respiciunt per accidens, et multo magis si accidentaliter per accidens. (Gerard, Summa, 6, 1; p. 368)

${ }^{24} \mathrm{Nec}$ Aristoteles dicit quod sermo audibilis sit causa discipline accidentaliter per accidens, sed solum dicit quod per accidens. Et iterum non dicit quod per accidens, nisi secundum quod audibilis, id est secundum quod est differencia soni qui per se est audibilis et auditus obiectum, sed secundum quod est significatiuus conceptus mentis. Innuit ibi Philosophus quod per se sit causa discipline, cum subdit: ex nominibus enim constat, et cetera. Quasi dicat: ipse sermo, ut mere audibilis est et auditus corporalis, obiectum per accidens confert ad disciplinam; ut uero est nomen significatiuum, sic non per accidens sed per se confert. (Gerard, Summa, 6, 1; p. 368)

${ }^{25}$ Circa tercium, est sciencium quod ad supernaturalia et credibilia cognoscenda, de quibus principaliter est ista sciencia, non sufficit lumen naturale, sed requiritur aliquod lumen supernaturale a deo menti infusum. Et quantum ad hoc, huius sciencie solus doctor est deus, pro quanto ipse solus tale lumen infundit. (Gerard, Summa, 6, 1; p. 368)
} 


\section{Conclusion}

It is disappointing that Gerard of Bologna left his Summa theologiae incomplete at the time of his death. In Quaestio 6, article 1 he addresses a number of issues in a preliminary manner. His account of the process of cognition in human beings represents an intriguing attempt to avoid both an illuminationist account and some version of the doctrine of intentional species. Gerard highlights the role of the natural light of the agent intellect working with the phantasm in the human process of coming to know while, of course, acknowledging God as the principal cause of all knowledge and principal teacher of the science of theology. Gerard's account offers a fascinating insight into philosophical controversy of his day. His own solution to the question of whether one human being may teach another per se insists on the dynamic relationship that obtains between teacher and student. In an interesting take on the medieval nominalist controversy, Gerard might also be seen to remind thinkers in all ages that even the most abstract or technical philosophical discussion of language and meaning is best rooted in the reality of person-to-person encounter and communication. For him there is much to be learnt from reflecting upon the teaching and learning dynamic itself. 
